\title{
Management education for a sustainable electric power industry in the 21 st century
}

\author{
L. D. Gitelman \\ Department of Energy and Industrial Management Systems, \\ Ural Federal University, Russia
}

\begin{abstract}
This paper presents the results of research and outlines the experience in the adoption of new methods for the training of energy managers that meet the $21 \mathrm{st}$ century challenges. The analysis shows that the management (both in energy companies and business consumers) are not qualified to operate on global and national competitive energy markets: managerial decisions there are taken amid high risk and uncertainty; decisions are often taken in response to changes in the external environment; new unconventional approaches are needed for a successful result; the price of a bad management decision grows substantially.

The empirical data that were obtained through the research shows the importance of the background knowledge of engineering and energy production technologies for managerial training; of developing readiness for innovative practices; of mastering pro-active self-development techniques. An interdisciplinary approach that puts together the "energy technologies - safety and environment - economics and finance - management" chain becomes the methodological foundation for energy training. The article looks at prerequisites, peculiarities and principles of global energy education and training of corporate managers, civil servants and other professionals who are involved in the electric power industry.

Keywords: globalization, electric power industry, sustainable development, education for global energy.
\end{abstract}

\section{Introduction}

Energy, universal access to energy sources are some of the key modern problems. It's no coincidence that the movement for solving this problem with the help of environmentally friendly technologies is led by the UN. 
Speaking about the electric power industry, the author suggests that for the sake of this subject we distinguish between two notions: sustainable functioning and sustainable development.

1. Sustainable functioning of the electricity sector means the ability of the industry at any one time to meet an economy's demand for electricity and capacity while

- $\quad$ safeguarding the appropriate level of security of supply;

- $\quad$ maintaining the system characteristics (frequency, voltage etc.);

- $\quad$ having a minimal impact on the environment;

- keeping electricity prices at a socially acceptable level (both for consumers and producers).

Sustainable functioning assumes the limited commissioning of new capacities for ensuring a reserve and renewal of fixed capital (replacement of decommissioned facilities and modernization); an increase in the throughput of transmission networks; the improvement of technological operation dispatch control systems.

Sustainable functioning is a permanent system of constant importance as it must be maintained in any economic circumstances, including recession. In different countries the issue is addressed universally: by means of maintaining present supply security, through cost management and certain organizational and technical innovations with low capital intensity.

2. Sustainable development of the electricity sector means its expansion in scale (launch of new capacities) to provide for economic growth and a higher electrification rate in the economy by introducing advanced power intensive processes. It also envisages a cascade of innovations, qualitative transformations in the industry (optimization of the generation structure and fuel and energy balance, introduction of eco friendly installations etc.) [1].

The sustainable development of the electricity sector is a prerequisite and consequence of economic growth. In the case of the lack of the latter (recession), the development of the electric power industry is held back, no technological breakthroughs happen. It should be emphasized that sustainable development is impossible without a sustainable operation of the electric power sector, which should be interpreted as a necessary but not sufficient condition.

It should also be noted that sustainable development is based upon the effective management of all types of risk that are generated by uncertainty in the external environment.

\section{Principles of global energy education}

Global energy education (GEE) of managerial personnel is aimed to acquiring knowledge and skills for confronting the challenges of strategic management of sustainable development in the electricity sector on the basis of technological and organizational innovations and the industry's integration into the global energy economy with an account of regional peculiarities. The purpose of such education is to train a world energy elite made up of highly qualified 
professionals who are capable of working for any organization and energy company in the world where the 21 st century energy policy is formed.

At the core of the educational programme are the methodological issues of creating a national energy policy and strategy for energy corporations through a systemic approach and analysis of long-term trends in the economy and energy while taking into account the geopolitical and economic interests of different countries, progressive technological and organizational ways of how the energy sector functions as well as methods of resolving conflicts between countries and contradictions in the sphere of energy economics. The programme is based on the following principles:

1. The introduction of versatile energy training that encompasses all structural elements of the fuel and energy sector, including the sector of energy consumption. The methodological approach corresponds with the structure of systemic ties within the fuel and energy sector: it is a large system consisting of a number of closely interrelated subsystems (gas, oil, coal, electricity, energy consumers).

2. The adoption of an interdisciplinary approach (technology environment - economics - finance and investment - international energy law - foreign trade - management).

3. Mastering the methods of prognostic scenario research into the prospects of the energy sector development.

4. Acquiring systemic knowledge of innovative energy development (technological, organizational, information and social aspects).

Considering the above-mentioned principles, the education programme is organized in five blocks (table 1).

The purpose of block 1 is to show correspondence between internal corporate management and systems for managing the industry's basic technical and technological peculiarities, its organizational and technical framework (the structure of generating capacity, distributed generation, average grid density etc.), the organization of production and innovation processes.

When presenting module 2, the focus is on world trends, opportunities and obstacles for adopting foreign innovations locally.

Block 3 analyses systemic economic and environmental problems in the context of limited natural resources and environmental assimilative capacity, creates an understanding of modern technologies that make it possible to solve these systemic problems.

Practical work in module 4 creates a comprehensive vision of problems and tasks that can be addressed with the help of knowledge and procedures borrowed from other areas of science.

A few comments on presenting the contents of the education problems and its methods:

1. The concept of global energy education is shaped as a result of the analysis of two groups of situational trends that determine new management tasks.

Group One. Present-day universal interdisciplinary trends that determine new content as well as methods of training: 
Table 1: $\quad$ The modules of education programme.

\begin{tabular}{|c|c|c|c|c|}
\hline $\begin{array}{l}\text { Economics } \\
\text { and } \\
\text { management } \\
\text { of energy } \\
\text { (block 1) }\end{array}$ & $\begin{array}{c}\text { Energy } \\
\text { globalization } \\
\text { issues } \\
\text { (block 2) }\end{array}$ & $\begin{array}{l}\text { Energy, } \\
\text { environment, } \\
\text { security } \\
\text { (block 3) }\end{array}$ & $\begin{array}{l}\text { Interdiscipli- } \\
\text { nary practice } \\
\quad(\text { block 4) }\end{array}$ & $\begin{array}{l}\text { Electives } \\
\text { (block 5) }\end{array}$ \\
\hline $\begin{array}{l}\text { - institutional } \\
\text { basis of the } \\
\text { industry } \\
\text { management; } \\
\text { - state } \\
\text { regulation; } \\
\text { - national and } \\
\text { regional } \\
\text { electricity } \\
\text { markets; } \\
\text { asset } \\
\text { management } \\
\text { in energy } \\
\text { companies; } \\
\text { - energy } \\
\text { efficiency } \\
\text { and energy } \\
\text { conservation. }\end{array}$ & $\begin{array}{l}\text { - international } \\
\text { energy } \\
\text { markets; } \\
\text { - cutting-edge } \\
\text { energy } \\
\text { technologies; } \\
\text { - culture of } \\
\text { energy } \\
\text { efficiency; } \\
\text { - international } \\
\text { energy law } \\
\text { and energy } \\
\text { standards. }\end{array}$ & $\begin{array}{l}\text { - environmental } \\
\text { and natural } \\
\text { resource } \\
\text { economics; } \\
\text { - innovative } \\
\text { conservation } \\
\text { technologies; } \\
\text { - safety and } \\
\text { security of } \\
\text { nuclear reactors } \\
\text { and major } \\
\text { power facilities; } \\
\text { - global } \\
\text { environmental } \\
\text { monitoring. }\end{array}$ & $\begin{array}{l}\text { - problem- } \\
\text { solving } \\
\text { workshops } \\
\text { with the } \\
\text { participation } \\
\text { of two or } \\
\text { three } \\
\text { experts } \\
\text { from } \\
\text { various } \\
\text { areas of } \\
\text { expertise; } \\
\text { organization } \\
\text { al activity } \\
\text { games; } \\
\text { innovation } \\
\text { projects. }\end{array}$ & $\begin{array}{l}\text { - valuation } \\
\text { of energy } \\
\text { companies; } \\
\text { - environ- } \\
\text { mental } \\
\text { audit; } \\
\text { - manage- } \\
\text { ment } \\
\text { teams; } \\
\text { - energy } \\
\text { consulting. }\end{array}$ \\
\hline
\end{tabular}

- The expansion of systemic relationships between business and a vast range of the most complex technologies. It is no coincidence that we are putting this trend on top of the list as it gives new, previously obscure, substance to other tendencies and essentially predetermines a new paradigm of managerial thinking.

- Overall intellectualization of managerial tasks. It is determined by qualitative changes in the essence, scale and complexity of problems that need to be handled amid considerable structural shifts in the technical, technological, resource and organization bases of manufacturing industries and against a background of unprecedented uncertainty and risk.

- Interdisciplinary approach accentuated. New multifaceted tasks that emerge in the course of overhaul and technological modernization dictate a constant need for a manager to acquire new knowledge in various fields and to communicate with a lot of experts.

Group Two encompasses industry trends that determine specific content of energy economic tasks:

- $\quad$ artificial competitive energy markets being organized by national governments; 
- $\quad$ substantial changes occurring in the technical principles of the functioning of electricity systems (Smartgrid, development of direct current systems, distributed generation, advanced automation), in the designing of safer and environmentally friendly NPPs with newgeneration reactors with improved safety characteristics, economically competitive renewable energy sources with energy storage units etc.);

- $\quad$ introduction of marketing programmes for demand-side management.

It is important to emphasize that the above-mentioned innovative trends are cost intensive and thus encourage international cooperation. At the same time, international integration assumes a global scale and become a key factor of sustainable energy. Prerequisites for this are stipulated by globalization processes in the energy sector that are of a clearly positive but controversial nature. These include:

- the creation of major electricity and pipeline systems connecting several countries that each has its own economic and political interests, all too often contradictory and changing ones. Such systems should operate under unified technical standards;

- the establishment of cross-national energy markets that function amid high risk and uncertainty in terms of demand for energy supplies, prices and investment resources;

- $\quad$ tougher environmental standards for the world energy sector as a global trend that is not only forward-looking, but also restrictive;

- $\quad$ recurrent factors of political and economic destabilization, oftentimes as a result of the lack of stability in the structure of energy exporters and importers;

- the accelerated spread of costly new energy technologies and methods of organizing the energy sector that are universal by nature, but whose effectiveness is uncertain in specific conditions of their application.

For the success of international integration for the sake for sustainable energy it is necessary to provide solutions to multifaceted problems; this requires one to be able to identify them and to create mechanisms for overcoming corresponding barriers (e.g., [2, 3]). Among the problems are: conflicting political and economic interests between some countries; the need to adapt technologies for the established structure of generating capacities; peculiarities of the grid network; the organization of energy markets; differences between national technical regulations and environmental standards; the state of the economy and living standards. Consequently, professional training that builds appropriate competencies, the quality of management and state regulation of the energy sector are on today's agenda.

2. Globalization, international cooperation, technological modernization of developing countries' energy sectors, the need to work ahead call for profound changes in the professional training of managers, effectively for a new education paradigm (Fig. 1). 
«as is»

\begin{tabular}{c}
\hline $\begin{array}{c}\text { From theory to solving real- } \\
\text { world tasks }\end{array}$ \\
\hline
\end{tabular}

Loading students, future managers with known information

- solving typical tasks with the use of conventional tools;

- copying best practices;

- designing new systems based upon known principles. «to be»

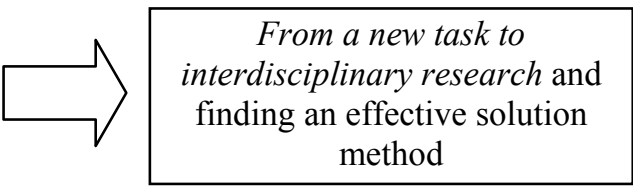

Training in work methods amid uncertainty

- ability to constantly update knowledge;

- ability to quickly collect, analyze and summarize information for a new task;

- forming methodological culture and conceptual thinking;

- teamwork skills.

Figure 1: General approach to designing a new education paradigm.

There is no unanimity of opinion in educational and scientific circles over the practical work component in university bachelor degree programmes. We believe that for addressing the issue it is worthwhile to distinguish three groups of industries:

those with simple production technologies that a young specialist can master within a few months upon entering the workplace; these are personal services, hotels and catering, retailing etc.

those with sophisticated production technologies that a manager needs to have knowledge of. Learning it takes time (usually, two to three years). Such are machine building; metallurgy, construction.

those with super sophisticated production technologies; the group includes power engineering, nuclear power production, aviation and space industry, the gas supply system, petrochemical industry etc. A manager will not be able to perform there without having mastered not only industry-related technical and technological knowledge, but also the most complicated interdisciplinary relationships between technology, economics, environment and the human factor.

Consequently, global energy education that builds competencies in the super sophisticated and potentially hazardous industries entails enhanced training in the field of engineering and technology.

Empirical data collected by the author of the research (Fig. 2) draw attention to the elements of management that are getting increasingly important in the electric power industry. For example, experts believe that more attention should be paid to engineering and technical issues of the sector and its scientific and technical prospects - up to 20-22 per cent of the curriculum for a bachelor's and master's degree; preparedness for innovation -12 per cent of the bachelor's 
degree curriculum and about the same share for master's (this aspect gets little attention in university programmes); self-learning techniques -15 per cent of the curriculum for bachelors and 11 per cent for masters (this competency is not taught at all at universities).

The new managerial training paradigm for energy workers could be implemented through a set of measures, the key ones being:

1. The development of a methodological culture of the energy manager.

It becomes a basic tool for scenario building and a new vision (strict conceptual framework; constructive approach to new information, problems and tasks; structuring; ability to see the big picture; ability to quickly build algorithms of response to new information; new circumstances).

2. The application of the interdisciplinary approach with an emphasis on technical expertise as an organization principle of the training process.

A background in power engineering and the knowledge of global scientific and technological trends are preconditions for a manager's ability to deliver. The volume and content of scientific, engineering, technological and economic training should be determined for managers of different specialties and status levels.

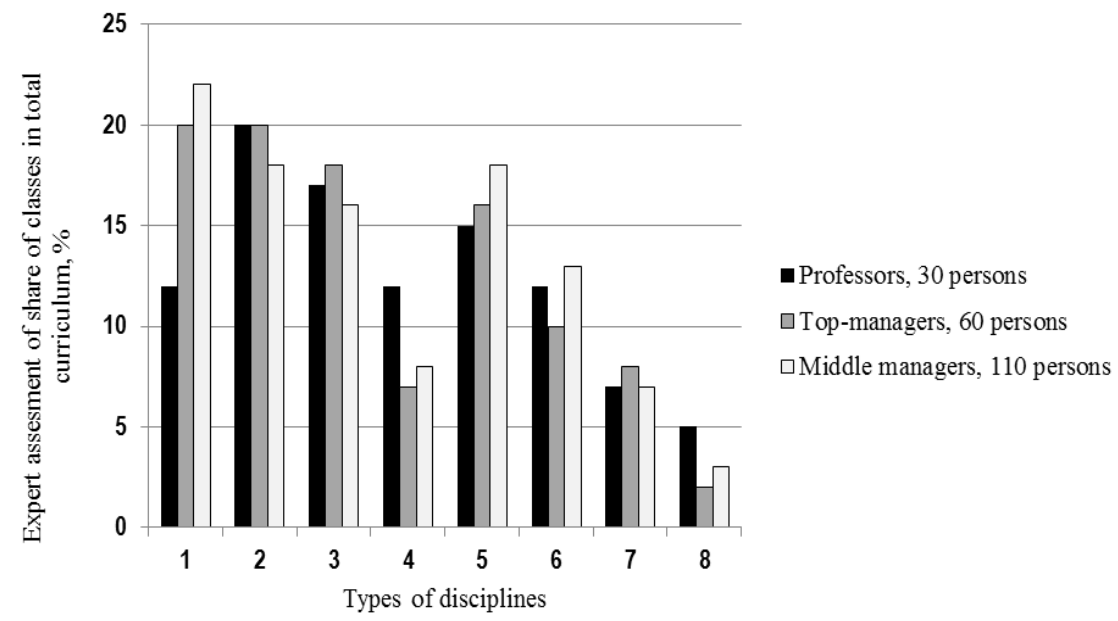

Figure 2: Share of disciplines in curriculum for bachelor of management: 1 - Science and engineering; 2 - Management (decision making, production engineering, HR management, organizational structures, planning, business strategy, leadership); 3 - Economics (industrial markets, business economics, finance, investment); 4 - Information handling (internet, professional software solutions, corporate knowledge and data bases); 5 - Self-learning techniques amid uncertainty; 6 - Preparedness to innovation and change; 7 - English and humanities; 8 Foreign economic activity of a company. 
3. The development of conceptual engineering skills in the context of modern innovative thinking (identifying the original idea - general concept; application of the target model; presentation of the structure of the new facility; application of "to be" normative models; assuring competence).

Acquiring competencies in creating strategies for technological and organizational development of the electric power sector (an electric power company) with respect to progressive global trends, national peculiarities and national competitive advantages.

In our practice, the new education paradigm is being implemented by employing a priority training method that nurtures the flexibility of professional thinking and behaviour, the learning of interdisciplinary relationships, understanding of the context and readiness to change. The Department for Energy and Industrial Management Systems at the Ural Federal University is designing a methodology called "ISKO" - "integrated system for consulting, training and transformation".

ISKO is a set of tools for active immersion of students and working managers in a problem-oriented environment that contains intellectual and motivational mechanisms for solving managerial tasks starting from the search for ideas to implementation of innovative solutions. The training model in ISKO is fundamentally different from the conventional one:

- the professor turns into the organizer of the teaching process, a consultant and a moderator;

- $\quad$ students actively discuss various issues, share information, collaborate and model situations jointly and gain insight;

- training is no longer about what the professor says, but about what the student is doing while working on a project;

- students perceive courses not as abstract disciplines, but as a practiceoriented complex that facilitates an interdisciplinary solution to real-life problems and their conceptual implementation.

Technologies that have been devised as part of the new education paradigm introduce algorithms and standards into the learning process, ensuring that it is aimed at building specific competencies, which is the target function of global energy education. The following technologies have been tested by the author:

- the energy manager's personal roadmap as their professional development tool;

- HR management as an incubator for an electric power company;

- $\quad$ an internet incubator for innovative leaders in energy;

- $\quad$ self-designing the future of an electric power company and creating training programmes for achieving it;

- $\quad$ ensuring the preparedness of the managerial personnel to modernization and organizational transformations;

- $\quad$ gamified solution "CLIMB to the acme of skill";

- continuous work on the strategy of a utility company in the developmental training mode; 
- $\quad$ training of innovation teams for the electric power industry;

- a collaborative innovation platform of the university and energy business;

- a digital simulator for energy managers;

- a continuing managerial education pipeline for electrical engineers who are promoted to managerial positions.

\section{Conclusion}

Today power engineering is already integrated in the process of globalization and internationalization. The process will grow, creating challenges for universities and calling for a global approach to managerial training. They determine radical changes in the paradigm and methods of education. In this connection, the author has designed a comprehensive methodology for energizing and supporting innovative processes in education and unique training technologies.

Some of the new elements that are related to energy globalization should be incorporated into courses of study in electrical engineering, too. To be more precise, engineers need to possess knowledge of international technical and environmental standards, technical and economic characteristics of cutting-edge energy equipment and delivery terms by individual manufacturers, effective service and maintenance systems, engineering structures etc.

On the basis of these causes, areas for improvement of competition and market environment have been determined and proposed models of the industry development have been substantiated.

\section{References}

[1] Gitelman, L.D. \& Ratnikov, B.E., Electricity Sector Reform: Effectiveness Evaluation and Adjustment of Policy, [in Russian]. Energy Market, 1, pp. 10-12, 2009.

[2] Rellaby, P., Uncertainties and risks in transitions to sustainable energy and the part trust might play in managing them: a comparison with the current pension crisis. Energy Policy, 38(6), pp. 2624-2630, 2010.

[3] Energy indicators for sustainable development, IAEA: Vienna, pp. 133-143, 2005. 